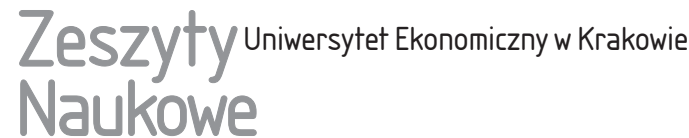

\section{Wpływ pandemii COVID-19 na działania CSR podejmowane przez przedsiębiorstwa}

\section{Streszczenie}

Cel: Celem badania było wykazanie, że podczas pandemii COVID-19 w Polsce przedsiębiorstwa podejmowały działania z zakresu społecznej odpowiedzialności biznesu.

Metodyka badań: Dane wykorzystane w badaniu zostały zgromadzone za pomocą analizy treści postów opublikowanych na profilach marek w serwisie Facebook od marca do maja 2020 r. oraz analizy danych zastanych.

Wyniki badań: Niespodziewana pandemia wymagała podjęcia określonych działań ze strony organizacji, m.in. dotyczących społecznej odpowiedzialności biznesu. Obszar ten stanowi również istotną lukę poznawczą. W artykule autorka podkreśliła znaczenie serwisu Facebook w komunikacji marek z odbiorcami oraz podjęła próbę klasyfikacji działań CSR zrealizowanych przez przedsiębiorstwa z różnych branż, które wspólnie dążyły do jednego celu, czyli przeciwdziałania skutkom pandemii. Było to m.in. przekazanie środków pieniężnych i podstawowych produktów, wsparcie akcji społecznej \#zostanwdomu, szycie maseczek ochronnych, stworzenie nowych produktów wspierających walkę z pandemią oraz podejmowanie dodatkowych działań prewencyjnych. Przedsiębiorstwa informowały odbiorców o podjętych inicjatywach za pomocą publikacji postów na swoich profilach w serwisie Facebook.

Angelika Czajkowska, Szkoła Doktorska Uniwersytetu Ekonomicznego w Krakowie, ul. Rakowicka 27, 31-510 Kraków, e-mail: angelika.czajkowska@phd.uek.krakow.pl, ORCID: https://orcid. org/0000-0003-3474-3286.

Artykuł udostępniany na licencji Creative Commons Uznanie autorstwa-Użycie niekomercyjne-Bez utworów zależnych 4.0 (CC BY-NC-ND 4.0); https://creativecommons.org/licenses/ by-nc-nd/4.0/ 
Wnioski: Należy wskazać, że pandemia COVID-19 znacząco wpłynęła zarówno na działalność gospodarczą wielu krajów, jak i na codzienne funkcjonowanie społeczeństwa, które postanowiło ograniczyć kontakt z innymi osobami i komunikować się za pomocą cyfrowych kanałów, takich jak np. media społecznościowe. Zmiany powstałe na skutek pandemii przyczyniły się do rozwoju CSR, co pokazano, prezentując sposób, w jaki nieprzewidziane okoliczności mogą warunkować podejmowanie określonych działań przez organizacje, a także kreować ich pozytywny wizerunek oraz wspierać społeczeństwo.

Wkład w rozwój dyscypliny: Zbadanie istoty działań podejmowanych przez przedsiębiorstwa z zakresu społecznej odpowiedzialności biznesu w czasie pandemii COVID-19. Pandemia COVID-19 stanowi nowe zjawisko, które wymaga szerszej analizy, a zaprezentowane wyniki badań przyczyniają się do zmniejszenia luki poznawczej w tym zakresie.

Słowa kluczowe: społeczna odpowiedzialność biznesu, pandemia, koronawirus, media społecznościowe, Facebook.

Klasyfikacja JEL: M14.

\section{Wprowadzenie}

Pandemia COVID-19 mocno wpłynęła na światową gospodarkę. Ze względu na zamknięcie granic odnotowano spadek międzynarodowej wymiany gospodarczej oraz konsumpcji prywatnej. Co więcej, działalność m.in. branży rozrywkowej, restauracyjnej, turystycznej, a także transportowej uległa spowolnieniu (wGospodarce.pl 2020). Był to bardzo ciężki czas także dla obywateli wielu państw, którzy musieli zmagać się z pandemią. Odczuwali oni lęk związany zarówno z możliwością zakażenia wirusem, utratą pracy, jak i dalszym funkcjonowaniem (Leśniewicz 2020). Pomimo strachu społeczeństwo czynnie włączyło się w działania charytatywne, takie jak m.in. opieka nad zwierzętami, pomoc w wykonaniu zakupów czy szycie maseczek (Społecznik 2.0 2020). Działania te stanowiły również istotne wyzwanie dla producentów marek, którzy musieli liczyć się z nadchodzącym kryzysem, otrzymując jednocześnie szansę realizacji działań z zakresu społecznej odpowiedzialności biznesu i kreowania pozytywnego wizerunku.

Celem badania było wykazanie, że podczas pandemii COVID-19 w Polsce przedsiębiorstwa podejmowały działania z zakresu społecznej odpowiedzialności biznesu. Problem badawczy stanowił brak wskazania rodzajów inicjatyw CSR (corporate social responsibility) podejmowanych przez przedsiębiorstwa w czasie pandemii, natomiast luką poznawczą było określenie działań zrealizowanych w tym obszarze. Autorka zgromadziła dane za pomocą analizy treści postów publikowanych na profilach marek w serwisie Facebook od marca do maja 2020 r. oraz analizy danych zastanych dotyczących badanego zjawiska. 


\section{Tło teoretyczne}

\subsection{Rozwój pandemii COVID-19 w Polsce i na świecie}

Uważa się, że pandemia COVID-19 wywołana przez koronawirusa SARS-CoV-2 (Gov.pl 2020a) miała swój początek w chińskim mieście Wuhan pod koniec 2019 r. Zdaniem Światowej Organizacji Zdrowia (WHO) pierwszy przypadek został odnotowany 8 grudnia 2019 r. (Gadzała 2020), natomiast wygasanie pandemii w Chinach zaobserwowano pod koniec marca $2020 \mathrm{r}$. W tym czasie potwierdzono tam 80928 infekcji oraz 3245 zgonów (Makarewicz 2020). Na skutek globalizacji pandemia przeniosła się także m.in. do Europy, gdzie 21 marca 2020 r. największą liczbę zakażeń i zgonów zaobserwowano we Włoszech. Według statystyk prowadzonych przez WHO odnotowano tam 47021 osób zakażonych i 4032 zgonów. Kolejnym krajem Europy, w którym zaobserwowano wysoką liczbę zakażeń, była Hiszpania. W dniu 6 kwietnia 2020 r. 130759 osób było zakażonych, a 12418 zmarło, podczas gdy we Włoszech w tym dniu liczby te wyniosły kolejno 128948 i 15899 .

Koronawirus dotarł także do Polski, determinując funkcjonowanie całego państwa. W Polsce 21 marca 2020 r. zakażonych było 425 osób, a 5 obywateli zmarło (WHO 2020a). Natomiast niespełna dwa miesiące później, 10 maja liczby te wzrosły do 15651 chorych oraz 785 zgonów (WHO 2020b). W Polsce wprowadzono wiele ograniczeń, które miały wesprzeć walkę z wirusem. Od 12 marca zawieszono m.in. zajęcia edukacyjne, a także ograniczono działalność placówek oświatowych i instytucji kultury (Premier.gov.pl 2020a), a 14 marca wprowadzono stan zagrożenia epidemicznego oraz ograniczono działalność galerii handlowych. Zamknięto siłownie, kluby fitness, restauracje, kawiarnie oraz bary, a lokale gastronomiczne mogły oferować swoje usługi jedynie na wynos i dowóz. Zakazano także zgromadzeń dla więcej niż 50 osób (Rządowe Centrum Bezpieczeństwa 2020). Co więcej, ograniczenia z biegiem czasu stawały się coraz bardziej rygorystyczne (Premier.gov.pl 2020b).

Od 19 kwietnia rozpoczęto tzw. odmrażanie gospodarki, wprowadzając pierwszy z jego czterech etapów. Zakładał on zmniejszenie ograniczeń dotyczących funkcjonowania placówek handlowych i usługowych. Kolejne etapy wdrożono 4 maja oraz 18 maja, a ostatni rozpoczął się 30 maja - zniesiono m.in. limit klientów w sklepach i restauracjach (Parp.gov.pl 2020).

Jesienią 2020 r. na skutek ponownie zwiększającej się liczby zakażeń wprowadzono nowe zasady bezpieczeństwa, a kraj został początkowo podzielony na strefę żółtą oraz czerwoną. W sferze żółtej obowiązywał m.in. nakaz zasłaniania nosa i ust w wolnej przestrzeni oraz ograniczono liczbę osób przebywających w restauracjach i siłowniach. Natomiast w strefie czerwonej wprowadzono m.in. zakaz 
organizacji wesel i imprez masowych oraz nauczanie zdalne w szkołach ponadpodstawowych i wyższych (Kieszek 2020). Następnie na skutek dynamicznej sytuacji epidemicznej cały kraj został objęty strefą czerwoną, a ograniczenia zostały zwiększone (Gov.pl 2020b).

\subsection{Istota społecznej odpowiedzialności biznesu}

Społeczną odpowiedzialność biznesu, czyli CSR, definiuje się jako koncepcję, zgodnie z którą firmy decydują się dobrowolnie przyczyniać do tworzenia lepszego społeczeństwa i czystszego środowiska (Commission of the European Communities 2001, s. 4). Według Światowej Rady Biznesu na rzecz Zrównoważonego Rozwoju jest to natomiast „ciągłe zobowiązanie biznesu do zachowania etycznego oraz przyczyniania się do zrównoważonego rozwoju ekonomicznego poprzez poprawę jakości życia pracowników i ich rodzin, jak również lokalnej społeczności i społeczeństwa jako całości” (Buczkowski i in. 2016, s. 15).

CSR zyskuje popularność wśród przedsiębiorstw, które dostrzegają, że należy przestrzegać określonych norm moralnych, etycznych oraz środowiskowych i być odpowiedzialnym za podejmowane decyzje (Wołoszyn Stawicka i Ratajczak 2012, s. 6). Aktywność w tym obszarze określa kierunek działań, promuje równe zasady konkurencji, a także pobudza do innowacyjności (Kromer 2014, s. 137). Działania z zakresu CSR są podejmowane w takich obszarach, jak (Chojnacka 2013, s. 54):

- rynek (m.in. przestrzeganie praw konsumentów oraz stosowanie podstawowych zasad etyki),

- miejsce pracy (np. tworzenie zasad bezpieczeństwa na stanowisku roboczym i przestrzeganie praw pracowniczych),

- społeczności lokalne (wsparcie lokalnych inicjatyw oraz wolontariat pracowniczy),

- środowisko naturalne (m.in. efektywne zużycie energii i innych zasobów naturalnych oraz redukcja emisji zanieczyszczeń).

Podczas kryzysu przedsiębiorstwa powinny dążyć do zamiany występujących zagrożeń w szanse zgodnie z modelem implementacji CSR w warunkach kryzysowych opracowanym przez J. Jonkera i M. De Wittego. Wykorzystuje się w tym celu takie czynniki, jak pozycja rynkowa organizacji, pozycja interesariuszy oraz zaufanie inwestorów. Kluczowa jest także dobra atmosfera, odpowiednia strategia firmy, głęboka refleksja wewnętrzna oraz wdrażanie innowacji (Gadomska-Lila 2012, s. 28-29).

\subsection{Facebook jako lider wśród serwisów społecznościowych}

W dawnych czasach społeczności komunikowały się bezpośrednio, co wymagało od odbiorcy i nadawcy przede wszystkim wzajemnej bliskości. Obecnie 
żyjemy w środowisku medialnym, gdzie popularne jest wykorzystanie mediów technicznych. Za ich pomocą użytkownicy pokonują zarówno czas, jak i przestrzeń, prowadząc tym samym do komunikacji zapośredniczonej (Goban-Klas 2004, s. 293).

Jednym z rodzajów mediów technicznych są media społecznościowe (Bąk 2016, s. 138-139). Definiuje się je jako „oparte na sieci serwisy, które pozwalają konstruować publiczny lub półpubliczny profil wewnętrznego powiązania, to serwisy pozwalające przedstawić listę użytkowników, z którymi dana jednostka ma powiązania, dające możliwość przejrzenia listy ich powiązań zarówno z innymi użytkownikami serwisu, jak i poza nim" (Boyd i Ellison 2008; za: Bąk 2016, s. 139). Serwisy społecznościowe stanowią jedno z najpopularniejszych narzędzi komunikacji w internecie. Użytkownicy prezentują tam siebie, swoje hobby i osiągnięcia. Istotna jest także rozległość posiadanej sieci (Bąk 2016, s. 139).

Media społeczne charakteryzuje m.in. (Fabjaniak-Czerniak 2012, s. 185):

- komunikacja dwukierunkowa,

- szybki przepływ i trwałość informacji,

- brak kontroli nad przepływem danych,

- mocne zaangażowanie uczestników tworzących komunikat,

- możliwość tworzenia wiadomości przez wszystkich zainteresowanych.

Z Facebooka korzysta ponad 60,6\% użytkowników internetu, co czyni go tym samym liderem wśród serwisów społecznościowych. Posiada on 2,6 mld aktywnych użytkowników miesięcznie, natomiast dziennie loguje się ich aż 1,73 mld. Istotny jest także fakt, że $65 \%$ społeczności ma poniżej 35 lat, większość użytkowników (96\%) loguje się do serwisu za pomocą urządzeń mobilnych, a średni czas spędzony dziennie na Facebooku wynosi prawie godzinę.

Ze względu na swoją popularność serwis ten stanowi także istotny kanał do realizacji działań marketingowych (Mohsin 2020), oferując użytkownikom wiele udogodnień, takich jak m.in. publikacja postów, zdjęć oraz komentarzy, wykorzystanie wewnętrznego komunikatora, logowanie się do innych stron za pomocą profilu na Facebooku, a także możliwość tworzenia nowych grup oraz dołączenia do istniejących (Szymański i Kowalczyk 2012, s. 265-266).

Komunikując się za pomocą Facebooka, organizacje mogą nawiązać pozytywne relacje z odbiorcami. Stają się także w ich opinii bardziej wiarygodne (Szymański i Kowalczyk 2012, s. 273-274). Co więcej, użytkownicy, wybierając źródła informacji na temat produktów i usług, kierują się wiarygodnością opinii (61\%), liczbą pozytywnych ocen w sieci $(58,10 \%)$, zaufaniem do osoby opiniującej (46,7\%), a także popularnością źródła (30,50\%) (Szuberski i Akacki 2019, s. 107). Kontakt z firmami za pomocą social mediów jest dla nich również bardzo istotny - 24,80\% ankietowanych preferuje rozmowę z przedsiębiorstwem na Facebooku, Messengerze lub Instagramie. Największy odsetek respondentów, czyli 33,30\%, 
woli zadzwonić do firmy, natomiast pozostali są zainteresowani kontaktem mailowym $(22,90 \%)$, osobistym $(11,40 \%)$ bądź wykorzystują w tym celu formularz zamieszczony na stronie internetowej $(7,60 \%)$. Dla badanych bardzo istotny jest również czas nawiązania kontaktu, szybkość otrzymania informacji zwrotnej i komfortowa komunikacja (Szuberski i Akacki 2019, s. 108-109).

\subsection{Zarządzanie komunikacją w mediach społecznościowych w czasie pandemii}

Według raportu przygotowanego przez firmę Endelman (2020) aż 70\% badanych poszukiwało informacji na temat koronawirusa przynajmniej raz dziennie, natomiast 30\% respondentów robiło to częściej. Co istotne, najbardziej obawiali się oni, że rozprzestrzeniane informacje są nieprawdziwe ( $74 \%$ badanych) oraz będą mieli trudność w znalezieniu wiarygodnych danych (45\%). Oczekiwali także udostępnienia większej liczby informacji przez naukowców (85\%).

Analizując źródła, które są najbardziej wiarygodne dla odbiorców, należy wskazać, że social media znalazły się na trzecim miejscu (38\%). Najbardziej zaufano głównym organizacjom informacyjnym (64\%), a następnie źródłom rządowym (40\%). Mniej wiarygodne były natomiast globalne (34\%) i narodowe (29\%) organizacje zdrowia, przyjaciele oraz rodzina (27\%), a także lokalne źródła rządowe (26\%). Wiek odbiorców również weryfikował pożądane źródło informacji, ponieważ 54\% użytkowników w wieku 18-34 lat korzystało z mediów społecznościowych, a odsetek ten wraz ze wzrostem wieku spadał. W przedziale wiekowym 35-54 lat wyniósł 38\%, a powyżej 55 lat 25\%. Należy zatem zauważyć, że social media odgrywają istotną rolę w życiu społeczeństwa, dostarczając mu wielu cennych i wiarygodnych informacji (Endelman 2020, s. 4-8). Organizacje wykorzystywały także media społecznościowe do budowania zaufania wśród odbiorców oraz zaprezentowania wartościowych dla nich treści.

W czasie pandemii m.in. tworzono reklamy nawiązujące do ówczesnej sytuacji oraz przedstawiano sposób, w jaki dostosowano się do zaistniałych zmian (np. jeżeli było to możliwe, zatrudnieni pracowali zdalnie). Dbano również o stały kontakt z klientami i zdalne zaspokajanie ich potrzeb, np. w postaci ćwiczeń online, wirtualnych wystaw czy oferowania posiłków na wynos (Invette 2020). Organizacje musiały jednak ostrożnie przygotowywać każdy komunikat, aby nie powodować dodatkowej paniki, dezinformacji bądź kryzysu wizerunkowego marki. Był to dla nich istotny sprawdzian z umiejętności dostosowania się do nowej sytuacji (Kozak 2020, s. 22).

Ze względu na wzmożoną liczbę publikacji dotyczących koronawirusa kluczowa była również umiejętna selekcja danych i ograniczone zaufanie względem autorów. Dlatego też Facebook oraz inne media społecznościowe 
takie jak Twitter czy Instagram zastosowały regulacje, które zakazywały reklam produktów i usług związanych z pandemią (m.in. maseczek ochronnych) i je usuwały. Serwisy współpracowały również z organizacjami WHO, CDC oraz UNICEF w celu weryfikacji i eliminacji fałszywych informacji z sieci. Co więcej, na Facebooku opublikowano komunikat dotyczący koronawirusa, który zachęcał użytkowników do sprawdzenia najnowszych wiadomości na stronie Ministerstwa Zdrowia (NowyMarketing 2020). Organizacje nieustannie dbały również o to, aby w realizowanych działaniach wykazać się empatią i jeżeli to możliwe, zaprezentować sposób, w jaki wspierały walkę z pandemią (Invette 2020).

\section{Metodologia}

Przedmiotem badania była treść postów opublikowanych przez przedsiębiorstwa w serwisie Facebook, dotycząca przeciwdziałania pandemii COVID-19 w Polsce, a także publikacje związane z omawianym zjawiskiem. Autorka analizowała treść postów opublikowanych na profilach marek w serwisie Facebook, aby pozyskać istotne informacje dotyczące zrealizowanych przez nich działań z zakresu CSR. Dążono do zapoznania się z aktywnością jak największej liczby przedsiębiorstw należących do różnorodnych branż, które prezentowały swoje zaangażowanie w walkę z pandemią. Był to m.in. Orlen, Poczta Polska, Żabka, Colian, Fundacja Lotto, GetIn Bank, Ikea, KGHM, Grupa PGE, Reserved, Wesołe Gary, Fitness Platinium, PZU, 4F, Orange oraz MediaMarkt.

Informacje zbierane były za pomocą zarówno wyszukiwarki Google, jak i serwisu Facebook. Ze względu na obszerny zakres danych opierano się na artykułach publikowanych w sieci, podążano za hasztagami wykorzystywanymi przez przedsiębiorstwa w serwisie Facebook (m.in. \#zostanwdomu, \#wzywamyposiłki, \#gastropomaga), analizowano profile marek pod względem podejmowanych działań, a także poszukiwano przedsiębiorstw, które realizowały podobne inicjatywy.

Dokonano także analizy danych zastanych związanych z omawianym zjawiskiem (publikacje dotyczące przedmiotu badań). Ze względu na dynamiczny rozwój pandemii były to głównie materiały dostępne online. Monitorowano również decyzje rządowe warunkowane zaistniałą sytuacją, które wpływały na inicjatywy CSR podejmowane przez obserwowane przedsiębiorstwa. Badania trwały od marca do maja $2020 \mathrm{r}$. 


\section{Wyniki badań i ich omówienie}

\subsection{Uwagi ogólne}

Facebook jest najczęściej wykorzystywanym serwisem społecznościowym, dlatego również podczas pandemii użytkownicy posługiwali się nim, aby wymieniać codzienne informacje. Marki nawiązywały natomiast relacje z odbiorcami i promowały m.in. social distancing, czyli konieczność utrzymania dystansu fizycznego pomiędzy dwiema osobami w celu uniknięcia zakażenia (Leksander 2020, s. 19). W publikowanych komunikatach dostrzeżono dwa kluczowe trendy, czyli reakcje przedsiębiorstw na aktualną sytuację i informowanie odbiorców o formach udzielanej pomocy z zakresu CSR, a także inspirowanie ich, jeżeli chodzi o sposób spędzania czasu w domu (Kozak 2020, s. 22).

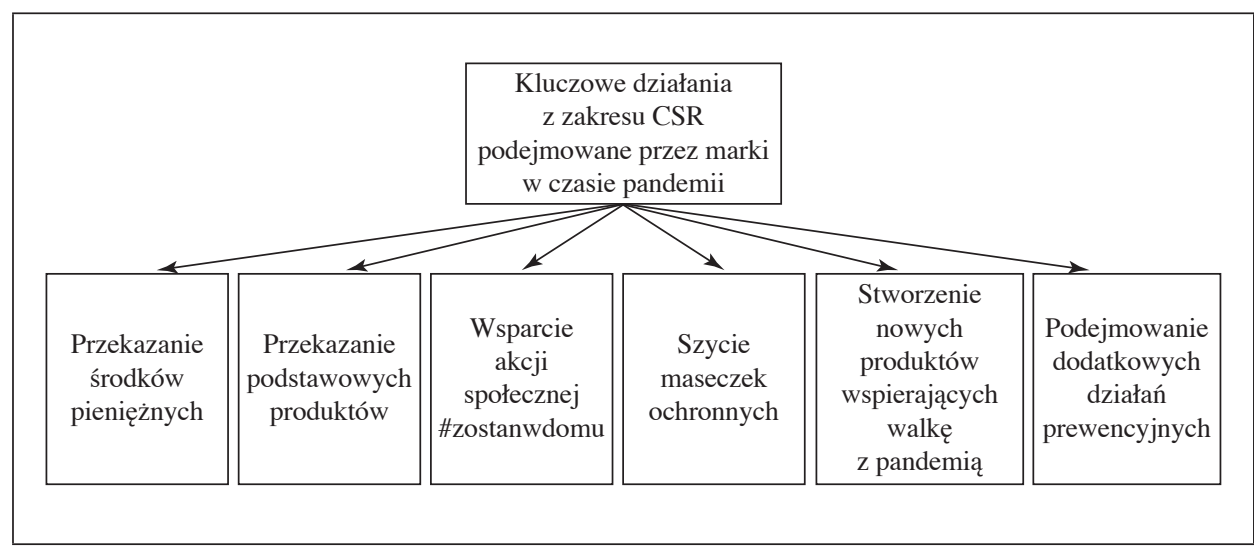

Rys. 1. Działania CSR podejmowane przez przedsiębiorstwa w czasie pandemii Źródło: opracowanie własne na podstawie (Facebook.com 2020).

Autorka dokonała analizy treści postów udostępnionych na profilach marek w serwisie Facebook, a następnie wyznaczyła kluczowe działania z zakresu CSR, które zrealizowano (rys. 1). Należy podkreślić, że w związku z panującą pandemią przedsiębiorstwa wspólnie dążyły do jednego celu, a podejmowane działania osiągnęły efekt kuli śnieżnej, jeżeli chodzi o tempo oraz zasięg prowadzonych akcji z zakresu CSR (Kozłowska 2020, s. 31). Nie sposób jest je wszystkie zaprezentować, ale warto wspomnieć, że „szybkie i sprawne działania, odpowiadanie na oczekiwania użytkowników oraz spełnianie aktualnych potrzeb to klucz do budowania wizerunku i świadomości marki. Nawet, a może przede wszystkim, w czasach zarazy" (Brzyska 2020, s. 35). 


\subsection{Przekazanie środków pieniężnych}

Przedsiębiorstwa zdecydowały się przekazać znaczne środki finansowe na walkę z koronawirusem. W szczególności Bank Pekao SA przeznaczył $5 \mathrm{mln}$ zł, salony Agata Meble $1 \mathrm{mln}$ zł, Grupa PGE 5 mln zł, Grupa Orlen 100 mln zł, Grupa Lotos $5 \mathrm{mln}$ zł oraz dodatkowo $2 \mathrm{mln}$ zł w postaci 400 kart paliwowych, Grupa KGHM Polska Miedź 15 mln USD, Fundacja KGHM Polska Miedź blisko 7 mln zł, PZU 6 mln zł, Żabka 4,5 mln zł, Fundacja Lotto 4 mln zł, Ikea Polska blisko 4,5 mln zł, a marka Reserved 1 mln zł oraz dodatkowo $10 \%$ zysków ze sprzedaży określonego produktu. Firma Kazar także przekazała 10\% zysków ze sprzedaży produktów, natomiast marka 4F $20 \%$ oraz dodatkowo całkowity zysk ze sprzedaży specjalnych T-shirtów. Marka Many Mornings przeznaczyła 50\% zysków ze sprzedaży specjalnych par skarpetek. Oczywiście nie są to jedyne marki, które zdecydowały się zaangażować w omawianą inicjatywę. Zgromadzone środki zostały wykorzystane m.in. przez szpitale, służby sanitarne, administrację rządową oraz organizacje trzeciego sektora (Facebook.com 2020). Informacje dotyczące ich zagospodarowania zostały zaprezentowane w dalszej części niniejszego artykułu.

\subsection{Przekazanie podstawowych produktów}

Drugim istotnym działaniem było przekazanie m.in. medykom oraz służbom publicznym podstawowych produktów. W tym celu zainicjowano akcje takie, jak np. \#posilekdlalekarza, \#gastropomaga oraz \#wzywamyposiłki. Inicjatywa \#posilekdlalekarza została zrealizowana za pomocą portalu Zrzutka.pl i polegała na przekazaniu personelowi medycznemu posiłków dostarczonych przez lokalne restauracje. Mogły one również zostać przygotowane dla osób hospitalizowanych z powodu koronawirusa, musiały być jednak zamówione przez personel medyczny. Aby otrzymać bezpłatny posiłek z restauracji, która brała udział w akcji, wystarczyło ją o tym fakcie poinformować. Następnie restauracja zgłaszała wydanie posiłku organizatorowi i otrzymywała zwrot kosztów (Zrzutka.pl 2020). Co istotne, restauracje, które brały udział w akcji, nawet po zakończeniu jej dofinansowania dalej przekazywały darmowe posiłki. Na przykład restauracja Wesołe Gary podwajała zawartość każdego zamówienia dla szpitala (Facebook.com 2020).

$\mathrm{Z}$ akcją \#posilekdlalekarza związana jest także inicjatywa \#gastropomaga. Przekazywanie darmowych posiłków przez lokalne restauracje zainicjowała restauracja Muszla Gdynia, która dostarczyła darmowe pizze personelowi medycznemu Szpitala Miejskiego w Gdyni (Gugniewicz 2020). W akcję włączyły się również następujące marki: Po Drodze - Coffee and Food, 3 Siostry Bajgel i Kawa, Todojutra, Pierogarnia Krakowiacy, Krowarzywa, Futu Sushi, Pasibus oraz wiele, wiele innych. 
Inicjatywa obywatelska \#wzywamyposilki także polegała na przekazaniu darmowych posiłków pracownikom medycznym. W akcję zaangażowały się m.in. następujące przedsiębiorstwa: KFC, Burger King, Pizza Hut, Starbucks, McDonald's, Costa Cofee, Ikea, Berlin Döner Kebap, Zielony Talerzyk, Tasca Ruczajnik oraz Makarun.

Co więcej, niektóre firmy nie działały w oparciu o żadną inicjatywę społeczną i dobrowolnie dostarczały swoje produkty placówkom medycznym. Na taki gest zdecydowała się m.in. marka Kuroniowie Diety, przekazując produkty o wartości 50 tys. zł, spółka Colian, przekazując 160 tys. sztuk produktów, a także Maspex, przesyłając potrzebującym ponad $1 \mathrm{mln}$ artykułów oraz 100 tys. zł szpitalowi w Wadowicach (w celu zakupu niezbędnych środków ochrony indywidualnej dla personelu medycznego i produktów spożywczych - również dla pacjentów).

Oprócz wsparcia personelu medycznego przedsiębiorstwa zdecydowały się także zadbać o służby publiczne. Koncerny paliwowe takie jak Shell, BP oraz Circle K wzięły udział w akcji „Darmowa kawa dla wszystkich służb”, oferując pracownikom służby publicznej darmową kawę na swoich stacjach. Akcja została zapoczątkowana przez markę Circle K. Grupa Lotos oferowała natomiast darmowe gorące napoje i napoje energetyzujące Dynamic dla służby przygranicznej oraz bezpłatne tankowanie pojazdów Pomorskiej Brygady Wojsk Obrony Terytorialnej na wybranych stacjach. Służby publiczne i służba zdrowia mogły również kupić tańsze paliwo, a służby mundurowe - dodatkowo wypić darmową kawę i kupić hot-doga w obniżonej cenie. Ponadto przedsiębiorstwo przekazało środki ochrony osobistej wybranej przychodni, 1,5 tys. płynów do dezynfekcji, a także razem ze spółką KGHM zorganizowało transport zakupionego sprzętu medycznego, który ważył aż 400 ton. Kolejny dystrybutor paliwa, Orlen oprócz zapewnienia darmowych napojów dla wojska, straży granicznej i służb celnych wspierał także kierowców oczekujących na wybranych przejściach granicznych, rozdając im zarówno napoje, jak i żywność. Marka maksymalnie obniżyła również ceny paliw, wspierała transport masek do Polski (które przekazano m.in. służbom medycznym i mundurowym) oraz dostarczyła maski ochronne, rękawice, kombinezony, gogle oraz płyny do dezynfekcji rąk i powierzchni domom pomocy społecznej. BP zapewniło szpitalom bezpłatne paliwo oraz oleje Castrol, a Shell przygotował bony paliwowe dla pojazdów szpitala w Warszawie i maski filtrujące dla jednostek pogotowia w kilku miastach, m.in. Warszawie, Kielcach, Rzeszowie oraz we Wrocławiu. Circle K przekazał z kolei 5 tys. paczek z żywnością i produktami pierwszej potrzeby seniorom w całej Polsce.

We wsparcie pracowników służb granicznych zaangażowała się również firma Berlin Döner Kebap, dostarczając swoje posiłki, oraz Platinium Fitness Club, przekazując wodę Polakom czekającym na przejściu granicznym, a także placówkom medycznym. Przedsiębiorstwo dostarczyło również m.in. chusteczki 
i płyny dezynfekujące, dwa telewizory oraz rowerek stacjonarny seniorom w Domu Spokojnej Starości w Krakowie, płyny do dezynfekcji szpitalom, a także płyny dezynfekujące, wodę i kosmetyki hospicjom. PZU sfinansowało natomiast zakup kombinezonów, maseczek, rękawów i środków dezynfekcyjnych dla policji oraz straży granicznej, a także przekazało 200 samochodów służbie medycznej i zaoferowało im pomoc psychologiczną. Grupa PGE zakupiła środki do odkażania, zorganizowała wolontariat pracowniczy i pomoc osobom starszym oraz wsparła infolinię NFZ, a KGHM oprócz wolontariatu pracowniczego angażowało się także w wykonywanie testów na obecność koronawirusa, przekazało obiady, wodę, kosmetyki pielęgnacyjne i fartuchy personelowi medycznemu oraz zorganizowało specjalny samolot, który dostarczył z Chin sprzęt medyczny w postaci respiratorów, kombinezonów, maseczek ochronnych, gogli medycznych i przyłbic.

Pracownicy banku Pekao SA pracowali natomiast na infolinii NFZ dotyczącej koronawirusa, Fundacja Lotto przekazała 90 samochodów dla szpitali potrzebujących transportu, 4F dostarczyło fartuchy oraz gogle narciarskie, Regioszulki zapewniło przyłbice i czapki, a Reserved oprócz przekazania fartuchów zaoferowało także wsparcie seniorom, podopiecznym domów dziecka i osobom bezdomnym. Ikea dostarczyła niezbędne produkty i posiłki, a pracownicy przedsiębiorstwa zaoferowali wsparcie rzeczowe szpitalom, pogotowiom ratunkowym oraz innym instytucjom wspierającym społeczeństwo. Poczta Polska zadbała natomiast o transport rękawiczek i płynów dezynfekujących dla szpitali (współpracując w tym celu z Ministerstwem Zdrowia) oraz zakupiła środki zabezpieczające dla pracowników o wartości $57 \mathrm{mln}$ zł. W celu poprawy bezpieczeństwa osób, które płacą bezgotówkowo, banki postanowiły również zwiększyć kwotę transakcji zbliżeniowych do 100 zł bez użycia kodu PIN. Informację tę na swoim profilu w serwisie Facebook zamieścił m.in. Bank Pekao SA, GetIn Bank oraz Santander (Facebook.com 2020).

Jak można zauważyć, przedsiębiorstwa oferowały różnorodne formy pomocy i nie sposób je wszystkie opisać. Należy także mieć na uwadze, że przekazywane produkty mogły zostać sfinansowane ze środków, które organizacje przeznaczyły na walkę z koronawirusem, często były to jednak dodatkowe działania.

\subsection{Wsparcie akcji społecznej \#zostanwdomu}

Kolejną akcją, w którą zaangażowały się marki, była inicjatywa \#zostanwdomu. Polegała ona na promowaniu przez organizacje, a także społeczeństwo pozostania w domu podczas pandemii. Zapoczątkował ją dziennikarz Krzysztof Stanowski, który umieścił hasztag w swoim wpisie na portalu Twitter. Wskazał on także, że podczas pandemii należy przebywać $\mathrm{w}$ domu, i poprosił, aby jego odbiorcy zaprezentowali sposób, w jaki spędzają czas ze swoimi dziećmi. Następnie w akcję włączyli się sportowcy, dziennikarze oraz inni użytkownicy. 
W marcu hasztag \#zostanwdomu był jednym z najbardziej popularnych hasztagów na Twitterze (DoRzeczy.pl 2020). Użytkownicy wykorzystywali go także m.in. w serwisie Facebook (\#zostanwdomu/\#zostańwdomu). W akcję \#zostanwdomu zaangażowały się marki takie, jak m.in.: MediaMarkt, Many Mornings, Santander, Lotto, Poczta Polska, Pekao SA, PZU, Grupa PGE, 4F, Ikea, Kazar, Wesołe Gary, Muszla Gdynia, Colian czy Pasibus. Trend ten został również rozwinięty o hasztagi \#uczsięwdomu czy \#trenujwdomu. Pierwszy z nich wykorzystały m.in. marki Orange i Morele.net, natomiast drugi pojawiał się głównie w komunikatach przedsiębiorstw z branży fitness, np. Platinium Fitness Club, Bieg Firmowy, Active Gym czy Avatar Centrala Ruchu. Niektóre marki stworzyły nawet własne odpowiedniki hasztagów, takie jak m.in. \#4Ftrenujzdomu, \#kazardlaszpitali, \#wolontariatKGHM, \#burgerdlamedyka (autorem hasztagu była restauracja Krowarzywa) oraz \#odwieszamkarnet (hasztag promujący utrzymanie opłaty za karnet na siłowni, która jest nieczynna). Orange w swoim materiale video wykorzystał natomiast wiele hasztagów jednocześnie, m.in. \#bawsięwdomu, \#czytajwdomu, \#surfujwdomu czy \#tańczwdomu (Facebook.com 2020).

\subsection{Szycie maseczek ochronnych}

Przedsiębiorstwa angażowały się także w szycie maseczek dla potrzebujących instytucji. Były to m.in. marki: John Cotton Europe, Motive \& More, Krosno Len Men, KGHM, 4F oraz Regioszulki (organizacja ze względu na małą skalę prowadzonej działalności szyła maseczki dla szpitali, wykorzystując w tym celu przekazane materiały, oraz jednocześnie produkowała maseczki dla swoich klientów). Co więcej, ochotnicy Grupy Lotos wykonywali maseczki dla pracowników i ich rodzin, a marka Reserved zdecydowała się przeznaczyć $1 \mathrm{mln}$ zł na zakup maseczek dla szpitali zakaźnych w Gdańsku i Krakowie oraz uruchomiła ich produkcję, aby wesprzeć instytucje zlokalizowane na Pomorzu i w Małopolsce. Łącznie przekazano ponad 250 tys. maseczek 40 polskim szpitalom i placówkom medycznym oraz ponad 5 tys. personelowi niemedycznemu. Spółka Colian przekazała natomiast 50 tys. maseczek ochronnych, Fitness Platinium - materiały potrzebne do ich wykonania, a Poczta Polska wspierała procesy logistyczne związane z dystrybucją (Facebook.com 2020).

Akcja oprócz wsparcia ze strony przedsiębiorstw była także realizowana przez krawcowe w ramach inicjatywy „Polskie Krawcowe uszyją maseczki ochronne dla służby zdrowia”. Polegała ona na wsparciu szpitali, które zgłaszały zapotrzebowanie na określoną liczbę maseczek, następnie dostarczano materiał do osób, które zajmowały się ich szyciem, a na końcu organizowano transport gotowych produktów do wybranej placówki (PolskaTimes.pl 2020). 


\subsection{Stworzenie nowych produktów wspierających walkę z pandemią}

Przedsiębiorstwa zdecydowały się także stworzyć specjalne produkty niezbędne podczas pandemii. Były to m.in. płyny do dezynfekcji. Marka Orlen dostarczyła wyprodukowany płyn służbom medycznym oraz umożliwiła jego zakup na stacjach benzynowych, podczas gdy KGHM przekazało płyny szpitalom, placówkom medycznym, urzędom, a także kopalniom i hutom. Nowością było również stworzenie koronkowych maseczek przez producenta rajstop Adrian, także w wersji z kolczykami (Facebook.com 2020).

\subsection{Podejmowanie dodatkowych działań prewencyjnych}

Warto zauważyć, że niektóre przedsiębiorstwa, takie jak np. KGHM czy Ikea, promowały również inicjatywy społeczne dotyczące m.in. sąsiedzkiego wsparcia. Zachęcały one użytkowników do skorzystania z przygotowanego formularza, za pomocą którego mogli oni zaoferować sąsiadom pomoc. Marka Ikea działała w ramach akcji wsparcia seniorów @pomagamy sobie, natomiast KGHM uczestniczyła w akcji \#wolontariatkghm.

Co więcej, banki takie jak Pekao SA i GetIn Bank zachęcały do wsparcia osób starszych podczas wykonywania transakcji online. GetIn Bank rozpoczął również akcję „Bierz internet za rogi” polegającą na wsparciu seniorów w korzystaniu $\mathrm{z}$ internetu.

Firmy publikowały na swoich profilach w serwisie Facebook także podstawowe informacje na temat koronawirusa i postępowania podczas kwarantanny, prezentowały ogólne zasady bezpieczeństwa lub te obowiązujące w miejscu sprzedaży, przekazywały informacje dotyczące noszenia maseczek i możliwości skorzystania z usług zdalnie oraz nawiązywały kontakt z odbiorcami (m.in. pytając o to, czym się zajmują podczas przebywania w domu). Zamieszczały w tym celu odpowiednią infografikę, materiały video lub tradycyjne komunikaty tekstowe, które zwracały uwagę odbiorców, a także wspierały kreowanie pozytywnych relacji z organizacją (Facebook.com 2020).

\section{Wnioski i podsumowanie}

Pandemia COVID-19 znacząco wpłynęła na funkcjonowanie większości organizacji, a także społeczeństwa, które w bardzo krótkim czasie musiało zmienić swój styl życia, dostosowując się do obecnych warunków.

Dostęp do sieci Internet umożliwił użytkownikom sprawniejszą i szybszą komunikację. Bez konieczności wychodzenia z domu mogli oni pozyskiwać 
istotne informacje dotyczące obecnej sytuacji na świecie, wykonywać obowiązki zawodowe, kształcić się, a także kontaktować z bliskimi. Była to wielka próba dla społeczeństwa medialnego, które musiało zrezygnować z bezpośrednich kontaktów i komunikować się za pomocą internetu, a w szczególności social mediów. W celu wymiany informacji wykorzystywano np. serwis Facebook. Przedsiębiorstwa za jego pomocą przekazywały m.in. kluczowe informacje dotyczące ich ograniczonej działalności w czasie pandemii oraz podejmowanych inicjatyw z zakresu CSR.

Dokonując analizy działań zrealizowanych przez marki w czasie pandemii, należy zauważyć, że pomimo iż działają one w zróżnicowanych sektorach, wspólnie dążyły do osiągnięcia wyznaczonego celu, czyli ograniczenia liczby zakażeń i zwalczenia pandemii. Dlatego też m.in. przekazywały środki pieniężne bądź podstawowe produkty potrzebującym organizacjom, a także produkowały np. płyny dezynfekujące. Wspierały również akcje społeczne i szyły maseczki.

Komunikaty opublikowane na profilach marek przed pandemią i w jej trakcie znacząco się różniły. Nawiązując do zamknięcia niektórych placówek oraz powagi sytuacji, większość przedsiębiorstw zamieszczała informacje na temat koronawirusa i wdrażanych działań prewencyjnych. Co więcej, marki wykorzystywały także dostępne hasztagi bądź tworzyły własne, aby promować realizowane przedsięwzięcia oraz kreować swój pozytywny wizerunek. Przedsiębiorstwa zaangażowane w działania z zakresu CSR dostrzegały istotność podejmowanych działań i konieczność wsparcia społeczeństwa, a także wyróżniały się na tle innych organizacji. Wykorzystywały w tym celu m.in. pozycję rynkową marki i odpowiednią strategię firmy, a także tworzyły dobrą atmosferę w przedsiębiorstwie. Należy zaznaczyć, że ze względu na duże zaangażowanie marek w działania CSR w czasie pandemii nie jest możliwe wymienienie wszystkich organizacji i podejmowanych inicjatyw.

\section{Literatura}

Bąk A. (2016), Serwisy społecznościowe - efekt Facebooka i nie tylko, „Media i Społeczeństwo", nr 6.

Boyd D.M., Ellison N.B. (2008), Social Networks Sites: Definition, History, and Scholarship, ,Journal of Computer-Mediated Communication”, nr 13 (1), https://doi. org/10.1111/j.1083-6101.2007.00393.x.

Brzyska A. (2020), \#ZostańwDomu ze sztukq. Działania instytucji kulturalnych w czasach zarazy (w:) Marka w czasach pandemii. Nowa rzeczywistość oczami Schulz brand friendly, https://www.schulz.com.pl/Marka_w_czasach_pandemii_Schulz.pdf (data dostępu: 8.04.2020).

Buczkowski B., Dorożyński T., Kuna-Marszałek A., Serwach T., Wieloch J. (2016), Społeczna odpowiedzialność biznesu. Studia przypadków firm międzynarodowych, Wydawnictwo Uniwersytetu Łódzkiego, Łódź. 
Chojnacka M. (2013), Założenia społecznej odpowiedzialności biznesu $w$ architekturze współczesnego otoczenia (w:) Społeczna odpowiedzialność biznesu, red. J. Rossa, M. Chojnacka, Państwowa Wyższa Szkoła Zawodowa im. Jakuba z Paradyża, Gorzów Wielkopolski.

Commission of the European Communities (2001), GREEN PAPER. Promoting a European Framework for Corporate Social Responsibility, https://ec.europa.eu/ commission/presscorner/detail/en/DOC_01_9 (data dostępu: 15.10.2020).

DoRzeczy.pl (2020), Koronawirus: W internecie trwa akcja „Zostań w domu”, https:// www.dorzeczy.pl/kraj/132584/koronawirus-w-internecie-trwa-akcja-zostan-w-domu. html (data dostępu: 23.03.2020).

Endelman (2020), Endelman Trust Barometer 2020, https://www.edelman.com/trustbarometer (data dostępu: 15.04.2020).

Fabjaniak-Czerniak, K. (2012), Internetowe media społecznościowe jako narzędzie public relations (w:) Zarzqdzanie w sytuacjach kryzysowych niepewności, red. K. Kubiak, Wyższa Szkoła Promocji, Warszawa.

Facebook.com. (2020), 3 Siostry Bajgiel i Kawa, 4F, Active GYM, ADRIAN Fabryka Rajstop, Avatar Centrala Ruchu, Bank Pekao S.A., Berlin Döner Kebap, Bieg Firmowy, bp, Circle K Polska, Colian, Fundacja LOTTO im. Haliny Konopackiej, FUTU SUSHI, Getin Bank, Grupa LOTOS, Grupa PGE, IKEApl, John Cotton Europe, Kazar, KGHM to my, Krosno Len Men, Krowarzywa, Kuroniowe Diety, Many Mornings, Maspex Kariera, MediaMarkt Polska, morele.net, Motive \& More, Muszla Gdynia, Orange, Pasibus, Pierogrania Krakowiacy, PKN ORLEN, Platinium Fitness Club, Po Drodze - Coffee and Food, Poczta Polska, PZU, Salony Agata, Santander Bank Polska, Shell, Regioszulki, Reserved, TODOJUTRA, Wesołe Gary, WzywamyPosiłki, ŻABKA - mały wielki sklep, https://www.facebook.com/ (data dostępu: 22.03.2020, 10.05.2020).

Gadomska-Lila K. (2012), Społeczna odpowiedzialność biznesu w obliczu kryzysu gospodarczego, ,Zeszyty Naukowe Uniwersytetu Szczecińskiego”, nr 28.

Gadzała Ł. (2020), Koronawirus pojawił się na świecie już w listopadzie?, https://www. euractiv.pl/section/bezpieczenstwo-i-obrona/news/koronawirus-pojawil-sie-na-swieciejuz-w-listopadzie (data dostępu: 21.03.2020).

Goban-Klas T. (2004), Media i komunikowanie masowe. Teorie i analizy prasy, radia, telewizji i Internetu, Wydawnictwo Naukowe PWN, Warszawa.

Gov.pl (2020a), Koronawirus - co musisz wiedzieć?, https:/www.gov.pl/web/zdrowie/ co-musisz-wiedziec-o-koronawirusie (data dostępu: 10.05.2020).

Gov.pl (2020b), Cała Polska w czerwonej strefie, kolejne zasady bezpieczeństwa oraz Solidarnościowy Korpus Wsparcia Seniorów, https://www.gov.pl/web/koronawirus/ cala-polska-w-czerwonej-strefie-kolejne-zasady-bezpieczenstwa-oraz-solidarnosciowykorpus-wsparcia-seniorow (data dostępu: 24.10.2020).

Gugniewicz J. (2020), \#GastroPomaga i \#PosiłekDlaLekarza-Restauracje z całej Polski wspierajq lekarzy $w$ walce z koronawirusem, https://nowymarketing.pl/a/25492, gastropomaga-i-posilekdlalekarza-restauracje-z-calej-polski-wspieraja-lekarzy-w-walcez-koronawirusem (data dostępu: 22.03.2020).

Invette (2020), Jakie marketingowe kroki podjać $w$ czasach pandemii koronawirusa COVID-19?, https://invette.pl/blog/jakie-kroki-marketingowe-podjac-podczas-pandemiicovid-19/ (data dostępu: 22.03.2020). 
Kieszek N. (2020), Rekordy zakażeń koronawirusem w całej Europie. Czy czeka nas kolejny lockdown?, https://strefainwestorow.pl/artykuly/gospodarka/20201015/koronawirus-w-europie (data dostępu: 16.10.2020).

Kozak N. (2020), Social media w erze koronawirusa - najciekawsze case’y przekucia pandemii w zasiegowy pozytywny sukces marek (w:) Marka w czasach pandemii. Nowa rzeczywistość oczami Schulz brand friendly, https://www.schulz.com.pl/Marka_ w_czasach_pandemii_Schulz.pdf (data dostępu: 8.04.2020).

Kozłowska D. (2020), Społeczna odpowiedzialność w dobie kryzysu (w:) Marka w czasach pandemii. Nowa rzeczywistość oczami Schulz brand friendly, https://www.schulz.com. pl/Marka_w_czasach_pandemii_Schulz.pdf (data dostępu: 8.04.2020).

Kromer B. (2014), Społeczna odpowiedzialność biznesu jako czynnik konkurencyjności przedsiębiorstw, ,Studia Ekonomiczne”, nr 180, cz. 2.

Leksander E. (2020), Alone Together, czyli jak technologia ratuje nas przed izolacja (w:) Marka w czasach pandemii. Nowa rzeczywistość oczami Schulz brand friendly, https://www.schulz.com.pl/Marka_w_czasach_pandemii_Schulz.pdf (data dostępu: 8.04.2020).

Leśniewicz M. (2020), Pomoc psychologiczna w zwiqzzu z epidemiq koronawirusa - wsparcie telefoniczne $i$ online, https://stronazdrowia.pl/pomoc-psychologiczna-wzwiazku-z-epidemia-koronawirusa-wsparcie-telefoniczne-i-online/ar/c14-14868723 (data dostępu: 2.04.2020).

Makarewicz N. (2020), Punkt zwrotny w walce z koronawirusem? Zero nowych przypadków w Whanie, https://www.rmf24.pl/raporty/raport-koronawirus-z-chin/najnowszefakty/news-punkt-zwrotny-w-walce-z-koronawirusem-zero-nowych-przy padkow, nId,4390526 (data dostępu: 25.03.2020).

Mohsin M. (2020), 10 Facebook Stats Every Marketer Should Know in 2020 (Infographic), https://www.oberlo.com/blog/facebook-statistics (data dostępu: 22.03.2020).

NowyMarketing (2020), Koronawirus w Internecie. Jak pandemia wpływa na marketing online?, https://nowymarketing.pl/a/25431,koronawirus-w-internecie-jak-pandemiawplywa-na-marketing-online (data dostępu: 22.03.2020).

Parp.gov.pl (2020), COVID-19: Rusza czwarty etap „odmrażania” gospodarki. Sprawdź, jakie ograniczenia przestanq obowiqzywać od 30 maja i 6 czerwca, https://www. parp.gov.pl/component/content/article/61365:covid-19-rusza-czwarty-etap-odmrazania-gospodarki-sprawdz-jakie-ograniczenia-przestana-obowiazywac-od-30-majai-6-czerwca (data dostępu: 12.08.2020).

PolskaTimes.pl (2020), Cała Polska szyje maseczki dla szpitali. Akcja wciqż trwa!, https://polskatimes.pl/cala-polska-szyje-maseczki-dla-szpitali-akcja-wciaz-trwa/ar/ c1-14863295 (data dostępu: 25.03.2020).

Premier.gov.pl (2020a), Premier: Podjęliśmy decyzję o zamknięciu wszystkich placówek oświatowych i szkół wyższych, https://www.premier.gov.pl/wydarzenia/aktualnosci/ premier-podjelismy-decyzje-o-zamknieciu-wszystkich-placowek-oswiatowych-i.html (data dostępu: 21.03.2020).

Premier.gov.pl (2020b), Premier: W walce z koronawirusem musimy utrzymać dystans społeczny, https://www.premier.gov.pl/wydarzenia/aktualnosci/premier-w-walce-zkoronawirusem-musimy-utrzymac-dystans-spoleczny.html (data dostępu: 2.04.2020).

Rządowe Centrum Bezpieczeństwa (2020), Stan zagrożenia epidemicznego, https://rcb. gov.pl/stan-zagrozenia-epidemicznego (data dostępu: 21.03.2020). 
Społecznik 2.0 (2020), Pomoc w czasach koronawirusa, https://spolecznik20.pl/posts/ pomoc-w-czasach-koronawirusa (data dostępu: 2.04.2020).

Szuberski P., Akacki D. (2019), Media społecznościowe jako narz̨dzie komunikacji rynkowej z klientem, „Akademia Zarządzania”, nr 3(3), http://info.wiz.pb.edu.pl/Nauka/ Czasopismo-Akademia-Zarządzania (data dostępu: 10.05.2020).

Szymański G., Kowalczyk A. (2012), Rola aplikacji reklamowych Facebooka we wspótczesnych strategiach marketingowych, ,Zeszyty Naukowe Uniwersytetu Szczecińskiego", nr 740 (31).

wGospodarce.pl (2020), Koronawirus a gospodarka - jakie skutki, jakie zagrożenia?, https://wgospodarce.pl/analizy/76649-koronawirus-a-gospodarka-jakie-skutki-jakiezagrozenia (data dostępu: 2.04.2020).

WHO (2020a), Novel Coronavirus (COVID-19) Situation Dashboard, https://experience. arcgis.com/experience/685d0ace521648f8a5beeee1b9125cd (data dostępu: 21.03.2020, 6.04.2020).

WHO (2020b), Poland: WHO Coronavirus Disease (COVID-19) Dashboard, https:// covid19.who.int/region/euro/country/pl (data dostępu: 10.05.2020).

Wołoszyn J. Stawicka E., Ratajczak M. (2012), Społeczna odpowiedzialność małych i średnich przedsiębiorstw agrobiznesu z obszarów wiejskich, Wydawnictwo SGGW, Warszawa.

Zrzutka.pl (2020), \#PosiłekDlaLekarza: wsparcie akcji \#WzywamyPosiłki, https://zrzutka. $\mathrm{pl} /$ posilekdlalekarza (data dostępu: 22.03.2020).

\section{Impact of the COVID-19 Pandemic on CSR Activities Undertaken by Enterprises}

(Abstract)

Objective: The aim of the study was to show that during the COVID-19 pandemic in Poland, enterprises took action in the field of corporate social responsibility.

Research Design \& Methods: The data used in this research was collected by analysing the content of posts published on brand profiles on Facebook from March to May 2020 and analysing the data.

Findings: The unexpected pandemic required organisations to take specific measures related to corporate social responsibility (CSR). In this article, the author emphasises the importance of Facebook in brand communication with recipients and classifies CSR activities carried out by enterprises operating in various industries that jointly pursued one goal - counteracting the effects of the pandemic. These were such activities as donating funds and basic products, supporting the social campaign \#zostanwdomu, producing protective masks, creating new products to support the fight against the pandemic and taking additional preventive actions. Enterprises informed recipients about the initiatives they were taking by publishing posts on their Facebook profiles.

Implications / Recommendations: The COVID-19 pandemic has greatly affected both the economic activity of many countries and the daily functioning of society, which limited contact among people and increased communications via digital channels such as social media. The changes resulting from the pandemic also make an essential contribution to the 
development of CSR by presenting how unforeseen circumstances may compel organisations to take specific measures to create a positive image and support society.

Contribution: The presentation of research on the CSR measures taken by enterprises during the COVID-19 pandemic. As a new phenomenon, the COVID-19 pandemic requires wider analysis. This paper helps reduce the cognitive gap.

Keywords: CSR, pandemic, coronavirus, social media, Facebook. 